\title{
Resiliensi Tahanan: Studi Literatur
}

\author{
Khosidah $^{1}$, Megah Andriany $^{1 *}$ \\ ${ }^{\mathbf{1}}$ Departemen Ilmu Keperawatan Fakultas Kedokteran, Universitas Diponegoro, Semarang, Indonesia \\ megahandriany@fk.undip.ac.id
}

\begin{abstract}
Introduction: Prevalence of mental health problems including detainees in prison are very high. Handling mental health problems is closely related to the ability of resilience in a person. Limited study review resilience, factors influencing it and instruments used in detainee. This study aims to describe the resilience of detainees, instruments to measure it, and factors influencing the resilience of detainees.

Methods: The research method used was literature review. Literature search was carried out using search keywords resilience, detainee, prison. The database used is SCOPUS, EBSCOHost, Garuda, Science Direct, ProQuest. Articles inclusion criteria are full-text articles from 2010-2020, published in English and Indonesian, and discussing resilience to detainees. Articles were identified using flow diagrams. Data were analysed using synthesis matrices.

Results: The results of search that has been conducted stating that the instruments used to identify resilience levels consisted of the Connor and Davidson Resilience Scale (CD-RISC), the resilience quotient compiled by Reivich and Shatte, the Resilience Measurement Scale (RMS-25), the Adolescent Resilience Attitudes Scale (ARAS), and the Norwegian adaptation of Dispositional Resilience scale (DRS-15-R). The average level of resilience of detainees is in the medium category. Resilience is influenced by age, ethnicity, family relationships, social relationships, self-acceptance, protective factors (pro-social) and (pro-future). Detainees are prone to mental health problems, because they have moderate levels of resilience.
\end{abstract}

Suggestion: Nursing services need to pay attention to the level of resilience of detainees.

Keywords: Deteainee, Prison, Resilience.

\begin{abstract}
Abstrak
Pendahuluan: Prevalensi masalah kesehatan mental termasuk sangat tinggi pada tahanan di Lembaga Pemasyarakatan. Penanganan masalah kesehatan mental erat kaitannya dengan kemampuan resiliensi pada seseorang. Penelitian ini bertujuan untuk mendiskripsikan gambaran resiliensi tahanan, instrumen untuk mengukurnya, dan faktor-faktor yang mempengaruhi resiliensi tahanan.

Metode: Metode penelitian yang digunakan adalah literature review. Pencarian literatur dilakukan dengan menggunakan kata kunci pencarian yaitu resilience, detainee, prison, resiliensi, tahanan, Lembaga Pemasyarakatan. Database yang digunakan adalah SCOPUS, EBSCOHost, Garuda, Science Direct, ProQuest. Artikel yang dipilih sebagai sumber data adalah artikel yang memenuhi kriteria inklusi sebagai berikut: artikel full-text, dari tahun 2010-2020, terpublikasi, berbahasa Inggris dan Indonesia, membahas mengenai resiliensi pada tahanan. Artikel diidentifikasi menggunakan flow diagram, kemudian data hasil temuan penelitian dianalisis dengan menggunakan matrik sintesis.

Hasil: Instrumen yang digunakan untuk mengidentifikasi tingkat resiliensi terdiri dari Connor and Davidson Resilience Scale (CD-RISC), resilience quotient yang disusun oleh Reivich dan Shatte,
\end{abstract}


Resilience Measurement Scale (RMS-25), the Adolescent Resiliency Attitudes Scale (ARAS), dan the Norwegian adaptation of Dispositional Resilience scale (DRS-15-R). Tingkat resiliensi tahanan ratarata berada dalam kategori sedang. Resiliensi tahanan dipengaruhi oleh faktor usia, etnis, hubungan keluarga, dukungan sosial, penerimaan diri, faktor protektif (pro-social) dan (pro-future). Tahanan rentan mengalami masalah kesehatan mental, memiliki tingkat resiliensi sedang.

Saran: Pelayanan keperawatan di Lapas perlu memperhatikan tingkat resiliensi pada tahanan.

Kata kunci: Lembaga Pemasyarakatan, Resiliensi, Tahanan.

\section{PENDAHULUAN}

Bureau of Justice Statistics mengungkapkan bahwa 44,3\% tahanan mengalami permasalahan tekanan psikologis, angka yang secara signifikan lebih tinggi $5 \%$ dari populasi umum (Bronson \& Berzofsky, 2017). Kondisi psikologis tahanan di Lapas dipengaruhi oleh beberapa faktor risiko. Maghnina mengungkapkan bahwa warga binaan yang baru masuk sebagai tahanan biasanya mengalami masalah psikologis yang disebabkan oleh faktor ekternal dan internal Lapas (Oktaviani, 2019). Pembinaan tahanan di Lapas dapat menimbulkan dampak psikologis. Semua akan mengarah pada tekanan mental yang hebat, yang mengakibatkan kecemasan, depresi, dan emosi negatif lainnya. Tekanan yang dialami oleh tahanan tidak menutup kemungkinan tahanan akan melakukan hal yang membahayakan diri tahanan sendiri maupun orang lain seperti kabur dari Lapas, membuat kerusuhan di Lapas, bahkan melakukan tindakan bunuh diri (Rohmanto, 2011).

Kemampuan yang harus dimiliki individu dalam keadaan yang menekan di Lapas berkaitan erat dengan resiliensi. Reivich dan Shatte menyatakan bahwa resiliensi merupakan kemampuan individu untuk beradaptasi terhadap kejadian yang berat atau masalah yang terjadi dalam kehidupan (Devi, 2015). Resiliensi merupakan kemampuan yang penting dalam diri seorang tahanan, karena dengan sikap resilien, tahanan akan mampu untuk beradaptasi, bertahan, dan bangkit dari peristiwa penuh tekanan.

Pengetahuan tentang resiliensi berasal dari developmental psychology literature. Studi pendahuluan literatur yang telah dilakukan oleh peneliti menunjukkan hasil bahwa tingkat resiliensi pada tahanan berada dalam kategori sedang, namun menunjukkan hasil presentase dengan tingkatan resiliensi yang berbeda-beda (Manarung, 2012; Pasudewi \& Undarwati, 2014; Zesong, Jihuang, \& Lihua, 2013). Sebagian besar tahanan memiliki tingkat resiliensi sedang. Studi literatur tentang tingkat resiliensi sangat diperlukan untuk mengetahui kemampuan resiliensi pada tahanan.

Pengukuran tingkat resiliensi biasanya dilakukan dengan menggunakan instrumen. Beberapa peneliti yang sudah melakukan penelitian tentang tingkat resiliensi tahanan menunjukkan perbedaan penggunaan intrumen yang dipakai oleh peneliti, salah satu diantaranya menggunakan kuesioner CD-RISC (Glowacz \& Born, 2015; Huang, et al., 2020; Sandvik, Hansen, Hystad, Johnsen, \& Bartone, 2015; Zesong, Jihuang, \& Lihua, 2013).

Tingkat resiliensi pada tahanan dipengaruhi oleh beberapa faktor. Peneliti 
telah melakukan studi pendahuluan literatur mengenai faktor yang dapat mempengaruhi resiliensi dan ditemukan hasil beberapa faktor yang berbeda. Salah satu diantara faktor yang mempengaruhi resiliensi adalah faktor risiko dan faktor protektif (Glowacz \& Born, 2015; Huang, et al., 2020; Markson, Lösel, Souza, \& Lanskey, 2015). Faktor yang memengaruhi resiliensi mempunyai peran yang sangat penting untuk diperhatikan dalam pengembangan intervensi untuk meningkatkan resiliensi pada tahanan. Terbatasnya telaah artikel terhadap instrument dan faktor yang berbeda di beberapa penelitian membuat peneliti tertarik melakukan literatur review terkait hal tersebut. Penelitian ini bertujuan untuk mendiskripsikan gambaran resiliensi tahanan dan instrumen untuk mengukurnya.

\section{METODE}

Metode penelitian yang digunakan adalah literature review dengan menggunakan berbagai sumber informasi dari artikel, jurnal dan buku yang relevan dengan topik penelitian. Database yang digunakan adalah SCOPUS, EBSCOHost, Garuda, Science Direct, Pro Quest. Kata kunci pencarian yaitu resilience, detainee, prison, resiliensi, tahanan, Lembaga Pemasyarakatan. Temuan dari berbagai sumber yang didapatkan dibatasi oleh kriteria inklusi sebagai berikut: artikel full text, terpublikasi dari tahun 2010-2020, berbahasa Inggris dan berbahasa Indonesia, membahas mengenai resiliensi pada tahanan.

\section{HASIL}

Identitas studi literatur ditampilkan pada diagram alir pencarian literatur. Artikel yang telah ditemukan dengan kata kunci dan jumlah artikel yang memenuhi kriteria inklusi akan dianalisis menggunakan matriks sintesis.

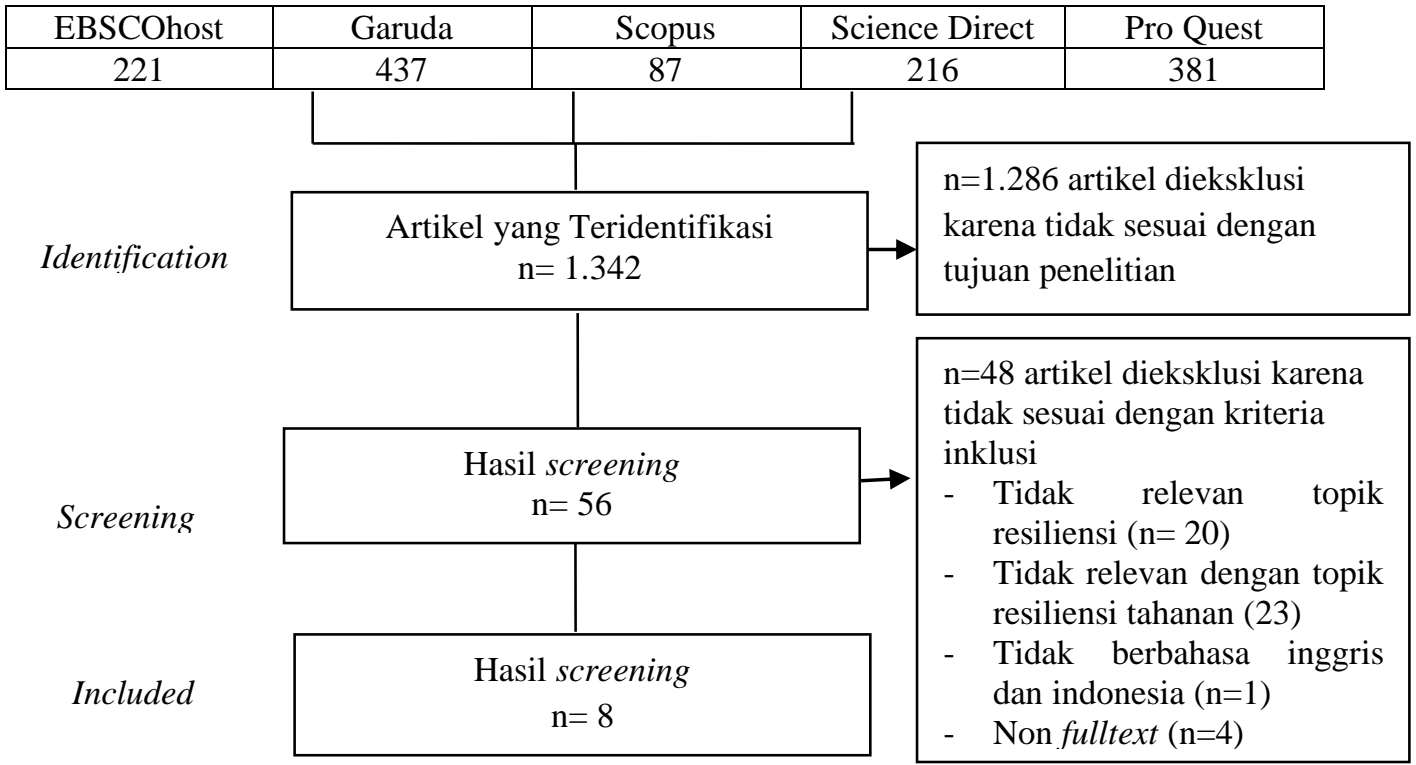

Gambar 1. Diagram proses pencarian dan seleksi literatur 
Tabel 1. Matriks Sintesis

\begin{tabular}{|c|c|c|c|c|c|c|c|}
\hline Judul & $\begin{array}{c}\text { Penulis \& } \\
\text { Tahun }\end{array}$ & Tujuan & Metode & Sampel & Temuan & Kesamaan & Keunikan \\
\hline $\begin{array}{l}\text { Resiliency, } \\
\text { risk, and } \\
\text { substance use } \\
\text { among } \\
\text { Hispanic } \\
\text { urban juvenile } \\
\text { detainees }\end{array}$ & $\begin{array}{l}\text { Elizabeth } \\
\text { R. Taylor, } \\
\text { Michael J. } \\
\text { Karcher, } \\
\text { Patricia } \\
\text { J.Kelly, } \\
\text { Smaranda } \\
\text { Valescu } \\
\text { (2003) } \\
\text { Dalam } \\
\text { Febrienne } \\
\text { Glowach } \\
\text { and Michel } \\
\text { Born } \\
\text { (2014) }\end{array}$ & $\begin{array}{l}\text { Untuk } \\
\text { mengetahui } \\
\text { proses resiliensi } \\
\text { pada tahanan } \\
\text { remaja }\end{array}$ & $\begin{array}{l}\text { Cross-sectional } \\
\text { survey research } \\
\text { design. } \\
\text { Menggunakan one- } \\
\text { way multivariate } \\
\text { analysis of variance } \\
\text { (MANOVA) }\end{array}$ & $\begin{array}{l}\text { Responden } \\
\text { sebanyak } \\
236 \\
\text { tahanan } \\
\text { dari dari } \\
\text { kota } \\
\text { Metropolit } \\
\text { an Texas } \\
\text { Selatan. }\end{array}$ & $\begin{array}{l}\text { Responden yang lebih tua dari } 15 \text { tahun } \\
\text { memiliki skor lebih tinggi dalam skala } \\
\text { inisiatif }(\mathrm{M}=3,59) \text {, relationship }(\mathrm{M}= \\
4,0) \text {, dan resiliensi total }(\mathrm{M}=3,61) \\
\text { dibandingkan dengan anak muda } 15 \\
\text { tahun atau lebih muda (inisiatif; } \\
\mathrm{M}=3,30 ; \text { relationship; } \mathrm{M}=3,56 ; \\
\text { resiliensi total: } \mathrm{M}=3,39) \text {. } \\
\text { Responden kulit putih tertinggi dalam } \\
\text { subskala kreativitas dan humor } \\
(\mathrm{M}=3,64) \text {, dan peserta kulit hitam } \\
\text { tingkat tertinggi dalam subskala } \\
\text { inisiatif (M=3,51). } \\
\text { Tidak ada hubungan antara subskala } \\
\text { resiliensi dengan penggunaan ganja } \\
\text { (p=0,47), penggunaan alkohol ( } \mathrm{p}=0,54) \\
\text { atau penggunaan narkoba ( } \mathrm{p}=0,41) . \\
\text { Hasil menunjukkan bahwa tidak ada } \\
\text { korelasi antara subskala resiliensi } \\
\text { dengan risk factor. Namun, terdapat } \\
\text { hubungan yang signifikan antara skala } \\
\text { resiliensi dan dua protective factors. }\end{array}$ & $\begin{array}{l}\text { Sama-sama } \\
\text { meneliti tentang } \\
\text { faktor yang } \\
\text { dapat } \\
\text { mempengaruhi } \\
\text { resiliensi } \\
\text { tahanan. } \\
\text { Diantaranya } \\
\text { faktor usia, } \\
\text { etnis, } \\
\text { penggunaan } \\
\text { obat terlarang, } \\
\text { serta faktor } \\
\text { protektif dan } \\
\text { faktor risiko. }\end{array}$ & $\begin{array}{l}\text { Meenggunak } \\
\text { an instrumen } \\
\text { The } \\
\text { Adolescent } \\
\text { Resiliency } \\
\text { Attitudes } \\
\text { Scale } \\
\text { (ARAS) }\end{array}$ \\
\hline $\begin{array}{l}\text { Resiliensi } \\
\text { pada remaja } \\
\text { binaan Bapas } \\
\text { ditinjau dari } \\
\text { coping stress }\end{array}$ & $\begin{array}{l}\text { Cantika } \\
\text { Yeniar } \\
\text { Pasudewi } \\
(2013)\end{array}$ & $\begin{array}{l}\text { Untuk } \\
\text { mengetahui } \\
\text { perbedaan } \\
\text { resiliensi pada } \\
\text { remaja binaan } \\
\text { Bapas ditinjau }\end{array}$ & $\begin{array}{l}\text { Jenis penelitian } \\
\text { kuantitatif, } \\
\text { menggunakan } \\
\text { desain komparatif }\end{array}$ & $\begin{array}{l}\text { Seluruh } \\
\text { klien } \\
\text { binaan } \\
\text { Bapas } \\
\text { Kota } \\
\text { Pekalonga }\end{array}$ & $\begin{array}{l}\text { Resiliensi pada sebagian besar remaja } \\
\text { binaan Bapas berada pada kategori } \\
\text { sedang, yaitu sebesar } 82,76 \%, 17,24 \% \\
\text { pada kategori tinggi dan tidak ada yang } \\
\text { berada pada kategori rendah. Seluruh } \\
\text { aspek resiliensi juga berada pada }\end{array}$ & $\begin{array}{l}\text { Menggunakan } \\
\text { instrumen skala } \\
\text { resiliensi Revich } \\
\text { dan Shatte }\end{array}$ & $\begin{array}{l}\text { Meneliti } \\
\text { tentang } \\
\text { tingkat } \\
\text { resiliensi } \\
\text { yang ditinjau } \\
\text { dari }\end{array}$ \\
\hline
\end{tabular}




\begin{tabular}{|c|c|c|c|c|c|c|c|}
\hline Judul & $\begin{array}{c}\text { Penulis \& } \\
\text { Tahun }\end{array}$ & Tujuan & Metode & Sampel & Temuan & Kesamaan & Keunikan \\
\hline & & $\begin{array}{l}\text { dari coping } \\
\text { stress }\end{array}$ & & $\begin{array}{l}\mathrm{n} \text { yang } \\
\text { berusia 12- } \\
21 \text { tahun }\end{array}$ & $\begin{array}{l}\text { kategori sedang. Spesifik masing- } \\
\text { masing aspek resiliensi yang berada } \\
\text { pada kategori sedang adalah sebagai } \\
\text { berikut: } \\
\text { - } \quad \text { Regulasi emosi } 81,04 \%, \\
\text { - } \quad \text { Pengendalian impuls } 56,9 \%, \\
\text { - } \quad \text { Optimisme } 65,52 \%, \\
\text { - } \quad \text { Causal analysis } 65,52 \%, \\
\text { - } \quad \text { Empati } 79,31 \% \\
\text { - } \quad \text { Self-efficacy } 68,97 \% \\
\text { - } \quad \text { Reaching out } 75,86 \%\end{array}$ & & $\begin{array}{l}\text { beberapa } \\
\text { aspek } \\
\text { Revich dan } \\
\text { Shatee. }\end{array}$ \\
\hline
\end{tabular}

\begin{tabular}{|c|c|c|c|c|c|c|c|}
\hline $\begin{array}{l}\text { Resilience as a } \\
\text { predicator of } \\
\text { mental health } \\
\text { of } \\
\text { incarcerated } \\
\text { women }\end{array}$ & $\begin{array}{l}\text { Ewa Sygit- } \\
\text { Kowalkow } \\
\text { ska, } \\
\text { Justyna } \\
\text { Szradja, } \\
\text { agdalena } \\
\text { Weber- } \\
\text { Rajek, } \\
\text { Krzysztof } \\
\text { Porazynski } \\
\text {, Marcin } \\
\text { Ziolkowski } \\
\text { (2016) }\end{array}$ & $\begin{array}{l}\text { Untuk } \\
\text { menganalisis } \\
\text { cara ketahanan } \\
\text { psikologis } \\
\text { membedakan } \\
\text { kondisi mental } \\
\text { wanita yang } \\
\text { dipenjara dan } \\
\text { untuk } \\
\text { mengidentifikas } \\
\text { i predikator } \\
\text { kesehatan } \\
\text { mental. }\end{array}$ & $\begin{array}{l}\text { Untuk menilai } \\
\text { konsistensi } \\
\text { distribusi variabel, } \\
\text { diperiksa dengan } \\
\text { distribusi normal, } \\
\text { uji Shapiro-Wilk. } \\
\text { Korelasi antara } \\
\text { variabel yang diuji, } \\
\text { akan diuji } \\
\text { menggunakan } \\
\text { korelasi } \\
\text { (Spearman's rho). }\end{array}$ & $\begin{array}{l}46 \text { tahanan } \\
\text { wanita di } \\
\text { penjara } \\
\text { pada usia } \\
25 \text { hingga } \\
64 \text { tahun. }\end{array}$ & $\begin{array}{l}\text { Hasil Pengukuran ingkat resiliensi } \\
\text { - } 20 \text { responden }(47,6 \%) \text { resiliensi } \\
\text { rendah } \\
\text { - } 7 \text { responden }(16,7 \%) \text { resiliensi } \\
\text { sedang } \\
\text { - } 15 \text { responden }(35,7 \%) \text { resiliensi } \\
\text { tinggi } \\
\text { Hasil HADS-M scale: } \\
\text { - } 11 \text { responden }(26,2 \%) \text { tidak } \\
\text { mengalami kecemasan } \\
\text { - } 2 \text { responden }(4,8 \%) \text { mengalami } \\
\text { kecemasan sedang } \\
\text { - } 29 \text { responden }(69 \%) \\
\text { mengindikasikan ditemukan } \\
\text { gangguan }\end{array}$ & $\begin{array}{l}\text { Sama sama } \\
\text { meneliti tentang } \\
\text { tingkat resiliensi } \\
\text { pada tahanan. }\end{array}$ & $\begin{array}{l}\text { Menggunaka } \\
\mathrm{n} \text { instrumen } \\
\text { Resilience } \\
\text { Measuremen } \\
t \text { Scale } \\
(\mathrm{RMS}-25)\end{array}$ \\
\hline $\begin{array}{l}\text { Resiliensi } \\
\text { Warga Binaan } \\
\text { Usia Dewasa }\end{array}$ & $\begin{array}{l}\text { Citra } \\
\text { Ekaris } \\
\text { Manurung, }\end{array}$ & $\begin{array}{l}\text { Untuk } \\
\text { mengetahui } \\
\text { tingkat resiliensi }\end{array}$ & $\begin{array}{l}\text { Metode deskriptif } \\
\text { kuantitatif }\end{array}$ & $\begin{array}{l}50 \\
\text { responden } \\
\text { warga }\end{array}$ & $\begin{array}{l}42 \% \text { WBP memiliki tingkat resiliensi } \\
\text { sedang, 30\% WBP memiliki tingkat } \\
\text { resiliensi tinggi dan 28\% WBP memili }\end{array}$ & $\begin{array}{l}\text { Sama-sama } \\
\text { meneliti tentang } \\
\text { tingkat resiliensi }\end{array}$ & $\begin{array}{l}\text { Menggunaka } \\
\mathrm{n} \text { instrumen } \\
\text { Resilience }\end{array}$ \\
\hline
\end{tabular}




\begin{tabular}{|c|c|c|c|c|c|c|c|}
\hline Judul & $\begin{array}{c}\text { Penulis \& } \\
\text { Tahun }\end{array}$ & Tujuan & Metode & Sampel & Temuan & Kesamaan & Keunikan \\
\hline $\begin{array}{l}\text { di Rutan Kelas } \\
\text { I Bandung }\end{array}$ & $\begin{array}{l}\text { Aat Sriati, } \\
\text { Nur } \\
\text { Oktavia } \\
\text { Hidayati } \\
(2012)\end{array}$ & $\begin{array}{l}\text { dan kemampuan } \\
\text { warga binaan } \\
\text { terhadap tujuh } \\
\text { faktor } \\
\text { pembangun } \\
\text { resiliensi }\end{array}$ & & $\begin{array}{l}\text { binaan } \\
\text { dewasa di } \\
\text { Rutan } \\
\text { Kelas I } \\
\text { Bandung }\end{array}$ & $\begin{array}{l}\text { tingkat resiliensi rendah. } \\
\text { Sebagian responden ( } 56 \%) \text { hanya } \\
\text { optimal pada satu faktor resiliensi yaitu } \\
\text { optimsme dan sebagian responden } \\
(50 \%) \text { kurang mengoptimalkan } \\
\text { kemampuan causal analysis. }\end{array}$ & tahanan & $\begin{array}{l}\text { Quotient } \\
\text { yang disusun } \\
\text { oleh Reivich } \\
\text { dan Shatte }\end{array}$ \\
\hline $\begin{array}{l}\text { The study on } \\
\text { resilience of } \\
\text { Detainees in } \\
\text { Lockup }\end{array}$ & $\begin{array}{l}\text { Dong } \\
\text { Zesong, } \\
\text { Zhang } \\
\text { Jihuang, } \\
\text { Zhang } \\
\text { Lihua } \\
\text { (2013) }\end{array}$ & $\begin{array}{l}\text { Untuk meneliti } \\
\text { resiliensi pada } \\
\text { tahanan dan } \\
\text { mendiskusikan } \\
\text { mengenai faktor } \\
\text { yang } \\
\text { mempengaruhi } \\
\text { resiliensi } \\
\text { tahanan }\end{array}$ & $\begin{array}{l}\text { Metode deskriptif } \\
\text { kuantitatif }\end{array}$ & $\begin{array}{l}\text { Sampel } \\
\text { sebanyak } \\
215 \\
\text { tahanan }\end{array}$ & $\begin{array}{l}\text { Tingkat resiliensi tahanan signifikan } \\
\text { rendah. Faktor pendidikan dan usia } \\
\text { mempengaruhi perbedaan tingkat } \\
\text { resiliensi pada tahanan }\end{array}$ & $\begin{array}{l}\text { Sama-sama } \\
\text { meneliti tentang } \\
\text { tingkat resiliensi } \\
\text { tahanan yang } \\
\text { dihubungkan } \\
\text { dengan faktor } \\
\text { yang } \\
\text { mempengaruhi }\end{array}$ & $\begin{array}{l}\text { Instrumen } \\
\text { yang } \\
\text { digunakan } \\
\text { adalah } \\
\text { Connor- } \\
\text { Davidson } \\
\text { Resilience } \\
\text { Scale (CD- } \\
\text { RISC) }\end{array}$ \\
\hline $\begin{array}{l}\text { Male } \\
\text { prisoners } \\
\text { family } \\
\text { relationships } \\
\text { and resilience } \\
\text { in resettlement }\end{array}$ & $\begin{array}{l}\text { Lucy } \\
\text { Markson, } \\
\text { Friedrich } \\
\text { Losel, } \\
\text { Karen } \\
\text { Souza, } \\
\text { Caroline } \\
\text { Lanskey } \\
(2015)\end{array}$ & $\begin{array}{l}\text { Untuk } \\
\text { menyelidiki } \\
\text { hubungan } \\
\text { keluarga pra- } \\
\text { penjara dan } \\
\text { kontak keluarga } \\
\text { selama } \\
\text { penahanan }\end{array}$ & $\begin{array}{l}\text { Studi longitudinal } \\
\text { prospektif dengan } \\
\text { metode wawancara }\end{array}$ & $\begin{array}{l}\text { Sampel } \\
\text { dari } 39 \\
\text { pasangan } \\
\text { keluarga } \\
\text { tahanan } \\
\text { pria } \\
\text { Inggris }\end{array}$ & $\begin{array}{l}\text { Nilai rata-rata pada hubungan keluarga } \\
\text { sebelum tindakan penjara adalah } 3,64 \\
(\mathrm{SD}=0,71) \text {, dan } 3,95(\mathrm{SD}=0,87) \\
\text { untuk kontak selama di penjara. } \\
\text { Temuan menunjukkan bahwa } \\
\text { hubungan keluarga yang positif penting } \\
\text { untuk mengembangkan resiliensi }\end{array}$ & $\begin{array}{l}\text { Sama-sama } \\
\text { meneliti tentang } \\
\text { faktor yang } \\
\text { mempengaruhi } \\
\text { resiliensi }\end{array}$ & $\begin{array}{l}\text { Meneliti } \\
\text { tentang } \\
\text { faktor } \\
\text { hubungan } \\
\text { keluarga } \\
\text { yang dapat } \\
\text { mempengaru } \\
\text { hi resiliensi }\end{array}$ \\
\hline $\begin{array}{l}\text { Psychological } \\
\text { resilience, } \\
\text { self- } \\
\text { acceptance, }\end{array}$ & $\begin{array}{l}\text { Yuanni } \\
\text { Huang, } \\
\text { Ruibin } \\
\text { Wu, Junkai }\end{array}$ & $\begin{array}{l}\text { Untuk } \\
\text { menganalisis } \\
\text { status kesehatan } \\
\text { mental pelaku }\end{array}$ & $\begin{array}{l}\text { Analisis korelasi } \\
\text { Pearson, regresi } \\
\text { linier berganda dan } \\
\text { Structural Equation }\end{array}$ & $\begin{array}{l}1106 \\
\text { partispan } \\
\text { yang } \\
\text { ditahan di }\end{array}$ & $\begin{array}{l}\text { Tingkat kesehatan mental, resiliensi } \\
\text { psikologis, penerimaan diri, dan } \\
\text { dukungan sosial yang dirasakan di } \\
\text { antara para pelaku pemenjaraan pada }\end{array}$ & $\begin{array}{l}\text { Menggunakan } \\
\text { instrumen } \\
\text { Connor and } \\
\text { Davidson }\end{array}$ & $\begin{array}{l}\text { Mengetahui } \\
\text { hubungan } \\
\text { resiliensi, } \\
\text { penerimaan }\end{array}$ \\
\hline
\end{tabular}




\begin{tabular}{|c|c|c|c|c|c|c|c|}
\hline Judul & $\begin{array}{c}\text { Penulis \& } \\
\text { Tahun }\end{array}$ & Tujuan & Metode & Sampel & Temuan & Kesamaan & Keunikan \\
\hline $\begin{array}{l}\text { perceived } \\
\text { social support } \\
\text { and } \\
\text { associations } \\
\text { with mental } \\
\text { health of } \\
\text { incarcerated } \\
\text { offenders in } \\
\text { China }\end{array}$ & $\begin{array}{l}\text { Wu, } \\
\text { Qingwen } \\
\text { Yang, } \\
\text { Shukai } \\
\text { Zheng, } \\
\text { Kusheng } \\
\text { Wu (2020) }\end{array}$ & $\begin{array}{l}\text { yang dipenjara } \\
\text { di Rutan dan } \\
\text { faktor yang } \\
\text { terkait, dan } \\
\text { memperkenalka } \\
\text { n resiliensi } \\
\text { psikologis, } \\
\text { penerimaan diri } \\
\text { dan dukungan } \\
\text { sosial }\end{array}$ & $\begin{array}{l}\text { Modeling (SEM) } \\
\text { digunakan untuk } \\
\text { mengidentifik-asi } \\
\text { asosiasi dan faktor- } \\
\text { faktor terkait }\end{array}$ & $\begin{array}{l}\text { dua pusat } \\
\text { penahanan } \\
\text { di Provinsi } \\
\text { Guangdon } \\
\text { g, } \\
\text { Tiongkok } \\
\text { dari } 1 \\
\text { Maret } \\
2019 \\
\text { hingga } 30 \\
\text { Mei } 2019 \text {. }\end{array}$ & $\begin{array}{l}\text { umumnya rendah, dan dipengaruhi oleh } \\
\text { faktor sosial-demografis. Penerimaan } \\
\text { diri dan daya tahan memediasi } \\
\text { hubungan antara persepsi dukungan } \\
\text { sosial dan kesehatan mental. } \\
\text { Skor untuk GHQ-20, CD-RISC, SAQ } \\
\text { dan PSSS masing-masing adalah } 7,72 \\
\pm 4,49,57,85 \pm 17,30,40,94 \pm 5,40 \text { dan } \\
42,99 \pm 9,90 \text {. Skor penerimaan diri (B } \\
=-0,23, \mathrm{P}<0,001) \text {, dukungan sosial (B } \\
=-0,10, \mathrm{P}<0,001) \text { dan ketahanan } \\
\text { psikologis }(\mathrm{B}=-0,06, \mathrm{P}<0,001)\end{array}$ & $\begin{array}{l}\text { Resilience Scale } \\
\text { (CD-RISC) }\end{array}$ & $\begin{array}{l}\text { diri, } \\
\text { dukungan } \\
\text { sosial, dan } \\
\text { kesehatan } \\
\text { mental pada } \\
\text { wanita yang } \\
\text { di Penjara }\end{array}$ \\
\hline $\begin{array}{l}\text { Psychopathy, } \\
\text { anxiety, and } \\
\text { resiliency- } \\
\text { Psychological } \\
\text { hardiness as a } \\
\text { mediator of } \\
\text { the } \\
\text { psychopathy- } \\
\text { anxiety } \\
\text { relationship in } \\
\text { a prison }\end{array}$ & $\begin{array}{l}\text { Asle M. } \\
\text { Sandvik, } \\
\text { Anita } \\
\text { L.Hansen, } \\
\text { Sigurd } \\
\text { William } \\
\text { Hystad, } \\
\text { Bjorn } \\
\text { Helge } \\
\text { Johnsen, } \\
\text { Paul T. } \\
\text { Bartone } \\
\text { (2015) } \\
\end{array}$ & $\begin{array}{l}\text { Untuk menguji } \\
\text { hubungan } \\
\text { resiliensi- } \\
\text { psychological } \\
\text { hardiness } \\
\text { dengan sifat- } \\
\text { sifat psikopati } \\
\text { dan kecemasan } \\
\text { yang dialami } \\
\text { dalam } \\
\text { pengaturan } \\
\text { penjara }\end{array}$ & $\begin{array}{l}\text { Kuesioner DRS-15- } \\
\text { R dan HADS } \\
\text { diberikan bersama } \\
\text { langkah-langkah } \\
\text { pelaporan diri } \\
\text { lainnya (mis., } \\
\text { demografi, sikap, } \\
\text { kesehatan umum). }\end{array}$ & $\begin{array}{l}\text { Partisipan } \\
\text { dalam } \\
\text { penelitian } \\
\text { ini adalah } \\
74 \text { tahanan } \\
\text { pria di } \\
\text { Bergen } \\
\text { Penjara, } \\
\text { Norwegia }\end{array}$ & $\begin{array}{l}\text { Ditemukan dua korelasi antara F1 dan } \\
\text { kecemasan dan } \mathrm{F} 2 \text { dan kecemasan } \\
\text { menjadi signifikan berbeda satu sama } \\
\text { lain }(\mathrm{ZH}=2.86, \mathrm{p}=.004) \\
\text { Psychological hardiness total dan } \\
\text { semua domainnya berkorelasi } \\
\text { signifikan dengan kecemasan (Total: } \mathrm{r} \\
=.568, \mathrm{p}=<.001 ; \text { Komitmen: } \mathrm{r}=.471 \text {, } \\
\mathrm{p}<.001 ; \text { Kontrol } \mathrm{r}=.363, \mathrm{p}=.002 \\
\text { Tantangan: } \mathrm{r}=.280, \mathrm{p}=.019)\end{array}$ & $\begin{array}{l}\text { Sama-sama } \\
\text { meneliti tentang } \\
\text { resiliensi yang } \\
\text { dihubungkan } \\
\text { dengan masalah } \\
\text { psikologis }\end{array}$ & $\begin{array}{l}\text { The } \\
\text { Norwegian } \\
\text { adaptation } \\
\text { of } \\
\text { Dispositiona } \\
\text { l Resilience } \\
\text { scale (DRS- } \\
\text { 15-R) }\end{array}$ \\
\hline
\end{tabular}


Berdasarkan hasil analisis beberapa artikel, peneliti menemukan beberapa tingkatan resiliensi pada tahanan. Hasil penelitian telah dipaparkan pada tabel matriks sintesis. Penelitian (Pasudewi dan Undarwati (2014) menunjukkan hasil bahwa $17,24 \%$ tahanan remaja binaan Bapas memiliki resiliensi tinggi, 82,76\% tahanan memiliki tingkat resiliensi sedang, dan tidak ada yang mempunyai resiliensi rendah.

Instrumen yang digunakan untuk mengukur resiliensi tahanan adalah kuesioner Connor and Davidson Resilience Scale (CD-RISC), kuesioner Reivich dan Shatte, kuesioner Resilience Measurement Scale (RMS-25), kuesioner the Adolescent Resiliency Attitudes Scale (ARAS), the Norwegian adaptation of Dispositional Resilience Scale (DRS-15-R) (Glowacz \& Born, 2015; Huang, et al., 2020; Pasudewi \& Undarwati, 2014; Sandvik, Hansen, Hystad, Johnsen, \& Bartone, 2015; Sygit, et al., 2017).

\section{PEMBAHASAN}

Resiliensi pada tahanan remaja
binaan Bapas presentase terbesar berkategori sedang, dapat diartikan bahwa remaja binaan Bapas cukup mampu untuk bertahan, menghadapi, dan tetap tenang di bawah kondisi yang menekan, sehingga cukup mampu untuk tetap berpikir positif dan optimis mengenai masa depan (Pasudewi \& Undarwati, 2014).

Kuesioner yang digunakan untuk mengukur resiliensi tahanan meliputi kuesioner Connor and Davidson Resilience Scale (CD-RISC), kuesioner Reivich dan Shatte, kuesioner Resilience Measurement Scale (RMS-25), kuesioner the Adolescent Resiliency Attitudes Scale (ARAS), the Norwegian adaptation of Dispositional Resilience Scale (DRS-15-R) (Glowacz \&
Born, 2015; Huang, et al., 2020; Pasudewi \& Undarwati, 2014; Sandvik, Hansen, Hystad, Johnsen, \& Bartone, 2015; Sygit, et al., 2017). Perbedaan dari kelima artikel alat ukur tersebut terletak pada jumlah item pertanyaan, penjabaran dimensi dan teori yang mendasari kuesioner.

Taylor, Karcher, Kelly, dan Valescu mengungkapkan bahwa faktor usia mempengaruhi resiliensi tahanan. Horn mengungkapkan bahwa stressor yang dihadapi usia dewasa madya lebih kompleks dan berat disbanding usia dewasa muda (Glowacz \& Born, 2015). Proses resiliensi yang dijelaskan oleh Wolin sama-sama relevan untuk kelompok etnis yang berbeda. Misalnya dalam mengatasi prasangka, stereotype, dan diskriminasi tentu saja mencerminkan proses resiliensi untuk etnis minoritas (Glowacz \& Born, 2015). Taylor, Karcher, Kelly, Valescu mengungkapkan bahwa subskala resiliensi tidak berkorelasi signifikan dengan faktor risiko. Resiliensi merupakan hasil dari proses dinamis dari faktor risiko dan faktor protektif, sehingga untuk mencapai kondisi resiliensi individu perlu memiliki faktor faktor yang dapat mendukung individu untuk menjauhi risiko atau dapat disebut sebagai faktor protektif (Glowacz \& Born, 2015). Markson, Losel, Souza, dan Lanskey (2015) mengungkapkan hubungan keluarga dapat membantu mengembangkan resiliensi. Hubungan keluarga yang positif juga berpengaruh terhadap kemampuan koping. Dukungan sosial dapat melindungi terhadap efek negatif dari stresor, dan individu yang memiliki akses ke jaringan dukungan sosial yang kuat, baik material atau emosional, cenderung memiliki penerimaan dan ketahanan diri yang lebih tinggi, dan dengan demikian lebih banyak emosi positif di sepanjang kesulitan. Dukungan sosial yang dirasakan dan 
penerimaan diri dianggap sebagai faktor perlindungan eksternal dan internal ketahanan (Plexico, Erath, Shores, \& Burrus, 2019).

\section{KESIMPULAN DAN SARAN}

Studi literatur menunjukkan hasil sebagian besar tahanan memiliki tingkat resiliensi sedang. Instrumen yang digunakan untuk mengukur tingkat resiliensi antara lain Connor and Davidson Resilience Scale (CD-RISC), resilience quotient yang disusun oleh Reivich dan Shatte, Resilience Measurement Scale (RMS-25), the Adolescent Resiliency Attitudes Scale (ARAS), dan the Norwegian adaptation of Dispositional Resilience Scale (DRS-15-R). Resiliensi tahanan dipengaruhi oleh beberapa faktor diantaranya faktor usia, etnis, dukungan keluarga, penerimaan diri, dukungan sosial, faktor protektif social dan future.

Saran untuk pelayanan keperawatan di Lapas diharapkan dapat mengetahui kondisi kesehatan mental dan kemampuan resiliensi tahanan di Lapas sehingga harapannya dapat menginisiasi pengembangan intervensi pro-social behaviour di Lapas dengan melibatkan partisipasi keluarga tahanan. Institusi pendidikan diharapkan dapat menerapkan pembelajaran tentang resiliensi dan menggunakan beberapa referensi instrumen resiliensi yang ada di dalam studi literatur ini untuk diterapkan dalam praktik pengkajian. Penelitian selanjutnya diharapkan dapat mengembangkan hubungan penelitian tentang faktor resiliensi dengan variabel lain yang berbeda.

\section{DAFTAR PUSTAKA}

Bronson, J., \& Berzofsky, M. (2017). Indicators of mental health problems reported by prisoners and jail inmates. Diperoleh dari https://bjs.ojp.gov/content/pub/pdf/i $\underline{\text { mhprpji1112.pdf }}$

Devi, R. R. P. (2015). Resiliensi narapidana dewasa di Lembaga Pemasyarakatan Klas IIA Sragen. Universitas Muhammadiyah Surakarta.

Glowacz, F., \& Born, M. (2015). Away from delinquency and crime: Resilience and protective factors. In J. Morizot \& L. Kazemian (Eds.), The Development of Criminal and Antisocial Behavior. London: Springer International Publishing Switzerland.

Huang, Y., Wu, R., Wu, J., Yang, Q., Zheng, S., \& Wu, K. (2020). Psychological resilience, selfacceptance, perceived social support and their associations with mental health of incarcerated offenders in China. Asian Journal of Psychiatry, 52, 102166. doi: 10.1016/j.ajp.2020.102166

Manarung, C. E. (2012). Resiliensi warga binaan usia dewasa di Rutan Klas I Bandung. Universitas Padjajaran.

Markson, L., Lösel, F., Souza, K., \& Lanskey, C. (2015). Male prisoners' family relationships and resilience in resettlement. 
Criminology and Criminal Justice, 15(4), 1-19. doi: $10.1177 / 1748895814566286$

Oktaviani, D. (2019). Problem penyesuaian diri warga binaan di Lapas Perempuan Kelas IIA Semarang. Universitas Islam Negeri Walisongo.

Pasudewi, C. Y., \& Undarwati, A. (2014). Resiliensi pada remaja binaan Bapas ditinjau dari coping stress. Intuisi: Jurnal Psikologi Ilmiah, 6(2), 92-97.

Plexico, L., Erath, S., Shores, H., \& Burrus, E. (2019). Self-acceptance, resilience, coping and satisfaction of life in people who stutter. Journal of Fluency Disorders, 59, 52-63.

Rohmanto, R. G. (2011). Self adjustment among inmates. Diperoleh dari https://adoc.pub/self-adjustmentamong-inmates.html

Sandvik, A., Hansen, A., Hystad, S. W., Johnsen, B. H., \& Bartone, P. (2015). Psychopathy, anxiety, and resiliency - Psychological hardiness as a mediator of the psychopathyanxiety relationship in a prison setting. Personality and Individual Differences, 72, 30-34. doi: 10.1016/j.paid.2014.08.009

Sygit, K., Ewa, S., Justyna, W. R., Magdalena, P., Krzysztof, Z., \& Marcin. (2017). Resilience as a predicator of mental health of incarcerated women. Psychiatria Polska, 51(3), 549-560. doi: 10.12740/PP/OnlineFirst/62617

Zesong, D., Jihuang, Z., \& Lihua, Z. (2013). The study on resilience of detainees in Lockup. 